University of Nebraska - Lincoln

DigitalCommons@University of Nebraska - Lincoln

Publications from USDA-ARS / UNL Faculty

U.S. Department of Agriculture: Agricultural

Research Service, Lincoln, Nebraska

3-1991

\title{
Maize Production Impacts on Groundwater Quality
}

J.S. Schepers

M.G. Moravek

E.E. Alberts

K.D. Frank

Follow this and additional works at: https://digitalcommons.unl.edu/usdaarsfacpub

This Article is brought to you for free and open access by the U.S. Department of Agriculture: Agricultural Research Service, Lincoln, Nebraska at DigitalCommons@University of Nebraska - Lincoln. It has been accepted for inclusion in Publications from USDA-ARS / UNL Faculty by an authorized administrator of DigitalCommons@University of Nebraska - Lincoln. 


\title{
Maize Production Impacts on Groundwater Quality
}

\author{
J. S. Schepers, ${ }^{*}$ M. G. Moravek, E. E. Alberts, and K. D. Frank
}

\begin{abstract}
The cumulative effects of management practices on nitrate-nitrogen $\left(\mathrm{NO}_{3}-\mathrm{N}\right)$ leaching and groundwater quality are frequently difficult to document because of the time required for expression and the diversity of interacting processes involved. This work reports results of a $\mathbf{N}$ and water management program initiated by the Central Platte Natural Resource District (CPNRD) in Nebraska. Cultural practices recommended by the CPNRD and reported by producers for the 1988 growing season, representing approximately 3900 fields covering 84210 ha of irrigated corn (Zea mays L.) indicated $\mathrm{NO}_{3}-\mathrm{N}$ contamination of groundwater was influenced by yield goals and fertilizer $\mathrm{N}$ application rates. Groundwater $\mathrm{NO}_{3}-\mathrm{N}$ concentrations were positively correlated with residual $\mathbf{N}$ in the surface $0.9 \mathrm{~m}$ of soil prior to the growing season, reflecting the effects of past $N$ and water management practices. Yield goals in 1988 averaged $9 \%$ higher than the average $10.0 \mathrm{Mg} \mathrm{ha}^{-1}$ corn yield attained, which accounts for an average of about $20 \mathrm{~kg} \mathrm{~N} \mathrm{ha}^{-1}$ in excess of the average $N$ recommendation. By comparison, in a 1980 to 1984 study from an area within the CPNRD, yield goals averaged $28 \%$ greater than actual yields. Overly optimistic yield goals in 1988 accounted for $42 \%$ of the average excess $N$ application rate of $48 \mathrm{~kg}$ $\mathrm{ha}^{-1}$ (based on University of Nebraska recommendations). A large portion of average excess $\mathbf{N}$ application is attributed to producers in $14 \%$ of the area who applied $>100 \mathrm{~kg} \mathrm{~N} \mathrm{ha}^{-1}$ more than the recommended rates. Fertilizer $N$ applied showed little relationship to fertilizer $\mathbf{N}$ recommended. Better education and more stringent measures may be required to address the select group of producers who fail to follow CPNRD recommendations.
\end{abstract}

$\mathrm{D}$ EGRADATION OF GROUNDWATER in rural areas is frequently attributed to agricultural production practices. Notable changes in groundwater quality that can be attributed to nonpoint sources of contamination may take years to develop and therefore represent the cumulative influence of past $\mathrm{N}$ and water management practices. The integrated effects of $\mathrm{N}$ and water management are frequently difficult to quantify in the soil vadose zone because of problems associated with obtaining representative soil samples. Therefore, examination of groundwater quality is frequently thought to be a reasonable integration of all management practices over a period of time.

Information to correlate cultural and management practices with groundwater quality is frequently limited because of the time lag between activities at the soil surface and the ultimate impact on the aquifer. Muir et al. (1973) used data from an extensive survey in Nebraska to show that $\mathrm{NO}_{3}-\mathrm{N}$ concentration in groundwater was positively correlated with irrigation

J.S. Schepers, USDA-ARS, Dep. of Agronomy, Univ. of Nebraska, Lincoln, NE 68583-0915; M.G. Moravek, Central Platte Natural Resource District, Grand Island, NE 68803; E.E. Alberts, USDAARS, Dep. of Agricultural Engineering, Univ. of Missouri, Columbia, MO 65211; and K.D. Frank, Dep. of Agronomy, Univ. of Nebraska, Lincoln 68583-0915. Contribution of USDA-ARS and Dep. of Agronomy, Univ. of Nebraska, and published as Journal Series no. 9185, Agricultural Research Division, University of NebraskaLincoln, Lincoln. Received 5 Feb. 1990. *Corresponding author.

Published in J. Environ. Qual. 20:12-16 (1991). well density, percentage of land area irrigated, $\mathrm{N}$ fertilizer use, and livestock density, but negatively correlated with soil $\mathrm{pH}$ and depth to groundwater. Such relationships support some of the general intuitive concepts related to the causes of groundwater contamination and leaching processes. However, the time required for these relationships to develop is frequently uncertain.

Because of the uncertainty in time between land treatment and the impact on groundwater, most research results are in the form of implied affects on groundwater. Few studies that initially showed the effect of land treatment on nutrient movement in the root zone or vadose zone, have been continued long enough to demonstrate the impact on groundwater quality and quantity. One such study site in western Iowa on a fine texture soil showed that excessive $\mathrm{N}$ application on nonirrigated corn resulted in $\mathrm{NO}_{3}-\mathrm{N}$ leaching to a depth of $4 \mathrm{~m}$ after $6 \mathrm{yr}$ and to $10.7 \mathrm{~m}$ after 15 yr (Alberts and Spomer, 1985a). Most of the $\mathrm{NO}_{3}-\mathrm{N}$ leaching in this work would be expected to occur outside of the growing season because evapotranspiration usually exceeds precipitation during much of the cropping season. Another aspect of this study compared conventionally tilled (plowing) with conservation tilled watersheds. Surface runoff was greater with conventional tillage, but base flow at the lower portion of the watershed was greater with conservation tillage. Summarization of the results over years showed that dissolved $\mathrm{N}$ losses (combined surface and base flow) were greater under conservation tillage (Alberts and Spomer, 1985b). Results of this work illustrate that even recommended production practices place a risk on groundwater quality, especially when excess fertilizer $\mathrm{N}$ is applied, but water remains the driving force behind $\mathrm{NO}_{3}-\mathrm{N}$ leaching.

The combined long term effects of excess fertilizer $\mathrm{N}$ application (448 $\left.\mathrm{kg} \mathrm{ha}^{-1}\right)$ and furrow irrigation from 1971 to 1979 resulted in $\mathrm{NO}_{3}-\mathrm{N}$ leaching below the root zone to a depth of $15 \mathrm{~m}$ in a fine texture loess soil in central Nebraska (K.D. Frank, 1989, personal communication). Subsequent coring in 1986 indicated the $\mathrm{NO}_{3}-\mathrm{N}$ had leached to nearly $20 \mathrm{~m}$ (Spalding and Kitchen, 1988). It was reassuring to find that fertilizer $\mathrm{N}$ rates necessary to attain near maximum corn yield in the above study resulted in less $\mathrm{NO}_{3}-\mathrm{N}$ leaching. However, studies such as this should provide a warning of pending groundwater contamination as $\mathrm{NO}_{3}-\mathrm{N}$ from untold years of overfertilization leaches to the aquifer.

Reports of municipal water supplies with $\mathrm{NO}_{3}-\mathrm{N}$ concentrations $>10 \mathrm{mg} \mathrm{L}^{-1}$ are becoming more common in Nebraska. Because of the many sources of $\mathrm{N}$ and other possible contributing factors (i.e., point sources and faulty well construction), it is frequently difficult to positively identify the source(s) of contamination. Considering that it may have taken a decade or more for the contamination to be detected or to reach maximum critical limits (recommended drink- 
ing water standard) in groundwater, it then follows that cleanup or remediation will likely also be a lengthy process.

An example of municipal well contamination comes from Sidney in western Nebraska where cores were taken from urban lawns within the city and up gradient sites characteristic of native prairie, irrigated corn fields, and a feedlot (Bryda, 1988). They found little residual $\mathrm{N}$ in the soil profile above the aquifer $(\sim 20$ $m$ ) under the urban lawns or native pasture, however substantial $\mathrm{NO}_{3}-\mathrm{N}$ was measured in the surface $2 \mathrm{~m}$ of the feedlot and throughout the entire profile under the irrigated corn field surrounding the feedlot. Little $\mathrm{NO}_{3}-\mathrm{N}$ leaching would be expected under active feedlots (Elliott et al., 1972; Ellis et al., 1975), however according to local residents, manure from the feedlot had been disposed of on adjacent corn fields for at least $20 \mathrm{yr}$. Records of annual manure loading were not available. Potentially mineralizable $\mathrm{N}$ determinations on soil surface horizons within the feedlot indicated high levels of decomposable organic $\mathrm{N}$ in the feedlot as expected (Saint-Fort, 1989). Surface soils of the adjacent corn fields receiving feedlot manure also contained high levels of mineralizable $\mathrm{N}$. Past $\mathrm{N}$ fertilizer applications on these corn fields had not compensated for the manure $\mathrm{N}$ credits. Therefore, excess amounts of $\mathrm{NO}_{3}-\mathrm{N}$ were undoubtedly available for leaching. Groundwater sampling indicated a plume of $\mathrm{NO}_{3}-\mathrm{N}$ originating near the feedlot had migrated to the city about $8 \mathrm{~km}$ down gradient (Bryda, 1988). Similar situations are developing in the Platte River Valley of central Nebraska where $\mathrm{NO}_{3}-\mathrm{N}$ concentrations in irrigation wells down gradient from several feedlots reached $79 \mathrm{mg} \mathrm{L}^{-1}$ in 1989 (1989, unpublished data courtesy CPNRD).

The need to properly credit manure and other $\mathrm{N}$ sources when making fertilizer $\mathrm{N}$ recommendations is becoming increasingly obvious. Proper credit is one goal to improve $\mathrm{N}$ management practices encouraged by the CPNRD where most of the irrigation wells have $\mathrm{NO}_{3}-\mathrm{N}$ concentrations $>10 \mathrm{mg} \mathrm{L}^{-1}$. The objective of this report is to summarize groundwater quality data collected during 1988 by the CPNRD and to characterize $\mathrm{N}$ management practices that may impact water quality.

\section{MATERIALS AND METHODS}

As the result of increasing groundwater $\mathrm{NO}_{3}-\mathrm{N}$ concentrations in the furrow irrigated region along the Platte River in central Nebraska, the CPNRD initiated a three-phase management program to address the contamination problem. Phase I areas have average groundwater $\mathrm{NO}_{3}-\mathrm{N}$ concentrations of $12.5 \mathrm{mg} \mathrm{L}^{-1}$ or less. Predominant areas with 12.6 to $20.0 \mathrm{mg} \mathrm{L}^{-1} \mathrm{NO}_{3}-\mathrm{N}$ in groundwater used for irrigation were designated as Phase II protection areas in 1987. Phase III areas have yet to be identified, but are intended where average $\mathrm{NO}_{3}-\mathrm{N}$ concentrations are $>20 \mathrm{mg} \mathrm{NO} \mathrm{N}_{3}-\mathrm{N}$ $\mathrm{L}^{-1}$. Land in the current Phase II areas is largely under corn production with limited amounts of soybean [Glycine max (L.) Merr.]. The nearly level alluvial soils in the designated area have textures that range from sandy loams to silty clay loams. Depth to water table typically ranges from 2 to 12 $m$. Furrow irrigation with groundwater is the predominant method of water application.

Efforts on the part of the CPNRD to reduce nitrate leach- ing involve a series of voluntary and mandatory $\mathrm{N}$ and water management practices. Producers on coarse texture soils are not permitted to apply $\mathrm{N}$ fertilizer in the fall and are limited to applications made after November 1 on other soils, and then only when an approved nitrification inhibitor is used. Fertilizer $\mathrm{N}$ recommendations were based on the amount of $\mathrm{N}$ required to reach a yield goal provided by producers minus the amount of residual $\mathrm{N}\left(\mathrm{NO}_{3}-\mathrm{N}\right)$ in soil samples collected

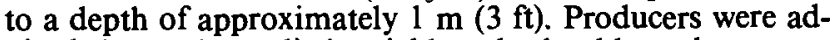
vised that to be realistic, yield goals should not be greater than 5\% above the 5-yr average of past production for each field. Fertilizer $\mathrm{N}$ recommendations were reduced for other sources of $\mathrm{N}$ not reflected by routine soil testing procedures (i.e., manures, legumes, and irrigation water) and for practices likely to improve $\mathrm{N}$ use efficiency (i.e., split $\mathrm{N}$ application, fertigation, and use of nitrification inhibitors). Although soil testing was performed by a number of commercial entities, all recommendations were consistent with University of Nebraska guidelines. Producers in the protection area are required to report all soil test information on each field to the CPNRD after harvest, as well as the grain yield goal, irrigation water applied, water $\mathrm{NO}_{3}-\mathrm{N}$ concentration, other $\mathrm{N}$ credits, fertilizer $\mathrm{N}$ recommended, fertilizer $\mathrm{N}$ applied, and actual grain yields. Guidelines for collection of irrigation water samples were that wells should be pumped for at least $2 \mathrm{~h}$ before sample collection and that two samples should be collected during the irrigation season. Typical irrigation well capacity in the area ranges from 2.3 to $3.8 \mathrm{~m}^{3} \mathrm{~min}^{-1}\left(\sim 600-1000 \mathrm{gal} \mathrm{min}^{-1}\right)$.

Data reported herein were submitted to the CPNRD following the 1988 growing season, and represented approximately $95 \%$ of the land under corn production in the Phase II protection areas. Nearly 4000 fields were represented, of which approximately 3900 were under irrigated corn production covering 84210 ha. Data were consolidated using three strategies. The first was based on the premise that if yield goals are overly optimistic, then fertilizer $\mathrm{N}$ recommendations would also be excessive. This consolidation consisted of calculating a relative yield (actual yield/yield goal) for each field and then grouping by increments of $5 \%$. The second type of data consolidation was based on the premise that $\mathrm{NO}_{3}-\mathrm{N}$ leaching and groundwater contamination would be affected by overfertilization. Deviation from fertilizer $\mathrm{N}$ recommendation ( $\mathrm{N}$ applied $-\mathrm{N}$ recommended) was calculated for each field and grouped by $11.2 \mathrm{~kg} \mathrm{~N} \mathrm{ha}^{-1}(10 \mathrm{lb}$ acre $^{-1}$ ) intervals. The third consolidation strategy was conducted to evaluate how closely producers followed fertilizer $\mathrm{N}$ recommendations. To accomplish this objective, fertilizer $\mathrm{N}$ recommendations were grouped by $11.2 \mathrm{~kg} \mathrm{~N} \mathrm{ha}^{-1}(10 \mathrm{lb}$ acre $^{-1}$ ) intervals and compared with actual $\mathrm{N}$ application rates. Statistics within groupings for each consolidation strategy were weighted by the area of the field under consideration.

\section{RESULTS AND DISCUSSION}

The most revealing correlation is that producers who exceeded fertilizer $\mathrm{N}$ recommendations also had the highest groundwater $\mathrm{NO}_{3}-\mathrm{N}$ concentrations (Fig. 1). These data probably present a glimpse of $N$ and water management practices over the past decade or more even though the $\mathrm{NO}_{3}-\mathrm{N}$ concentrations are plotted relative to 1988 fertilizer $\mathrm{N}$ practices. Because of the shallow depth to groundwater $(2-12 \mathrm{~m})$, it is reasonable to assume that only a small portion of $\mathrm{N}$ in groundwater can be attributed to the 1988 fertilizer $N$ application. It is recognized that most people, including farmers, seem to be victims of habit and are slow to make major changes unless there are strong driving forces such as economics or mandatory regulations. 


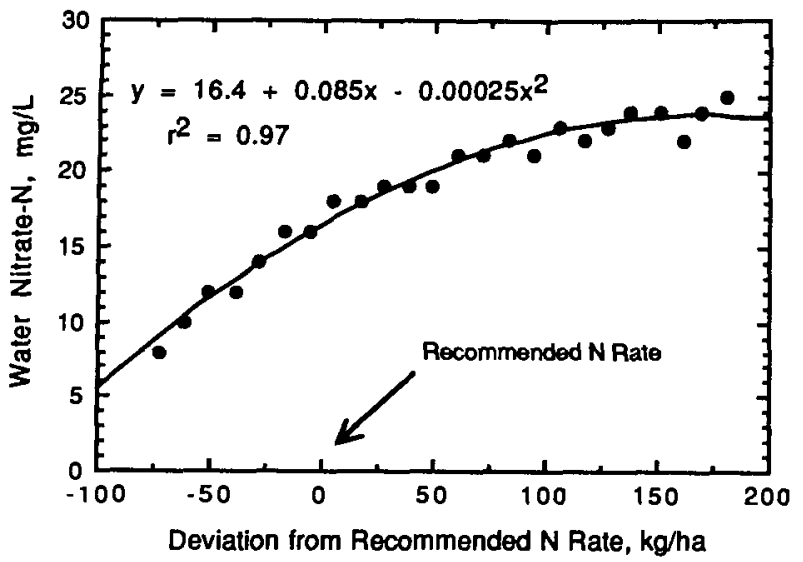

Fig. 1. Nitrate-N concentration in irrigation wells for land within the CPNRD Phase II protection area receiving various amounts of $\mathbf{N}$ fertilizer relative to recommended amounts.

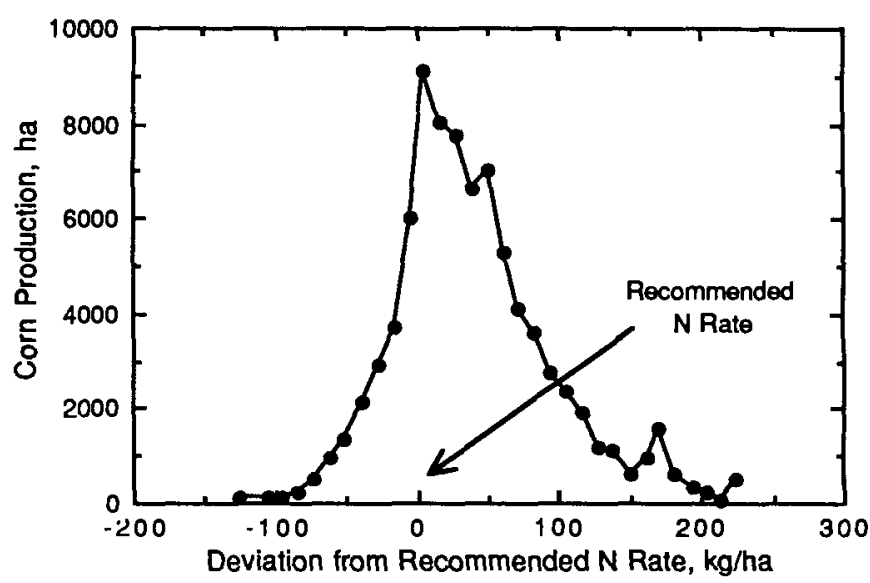

Fig. 2. Distribution of corn production within the CPNRD Phase II protection area receiving various amounts of $\mathbf{N}$ fertilizer relative to recommended amounts.

Therefore, it is hypothesized that current producer attitudes relative to soil testing and fertilizer $\mathrm{N}$ recommendations have also persisted for a number of years. This point can be illustrated by a group of producers who were advised not to apply any fertilizer because of high levels of residual $\mathrm{N}$ in soil $\left(>350 \mathrm{~kg} \mathrm{ha}^{-1}\right.$ in $0.9-\mathrm{m}$ depth), but still applied an average $224 \mathrm{~kg} \mathrm{~N}$ $\mathrm{ha}^{-1}$ (Fig. 2). If this hypothesis is correct, it could explain the positive relationship between fertilizer applied in 1988 and $\mathrm{NO}_{3}-\mathrm{N}$ in groundwater.

Since fertilizer $\mathrm{N}$ recommendations are usually based on yield goals, it is necessary to evaluate over projected yields as a cause for excess $\mathrm{N}$ fertilization.

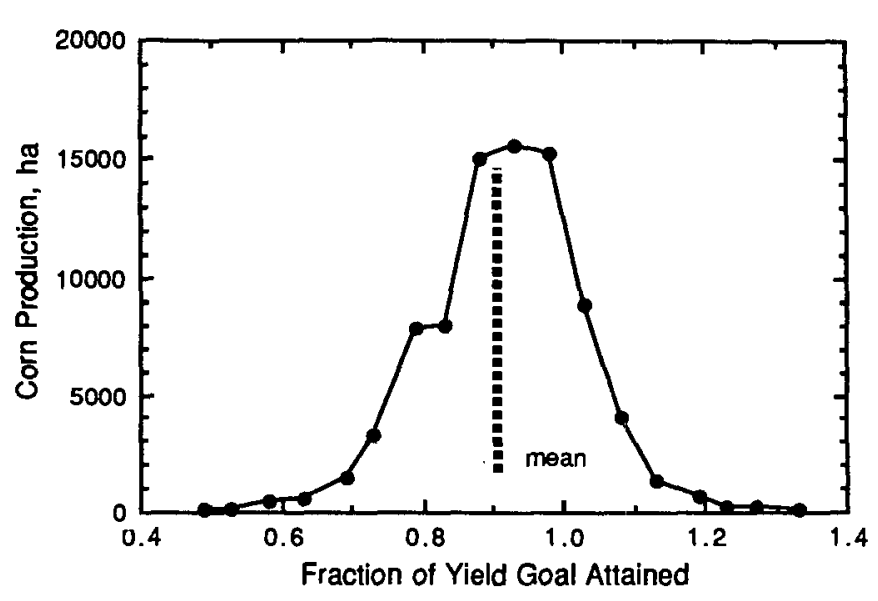

Fig. 3. Distribution of corn production within the CPNRD Phase II protection area relative to the fraction of the yield goal attained by producers.

These yield goals averaged $9 \%$ higher than mean yields $\left(10.0 \mathrm{Mg} \mathrm{ha}^{-1}\right.$ ) reported by producers (Fig. 3 ). It should be noted from the standard deviation that most producers were able to attain at least $65 \%$ of their yield goals and a few were able to exceed their yield goals by more than $17 \%$. The overly optimistic average yield goal translates into approximately $20 \mathrm{~kg} \mathrm{~N} \mathrm{ha}^{-1}$ in excess fertilizer recommendations. By comparison, in a 1980 to 1983 study (Schepers et al., 1986) yield goals from an area within the CPNRD averaged $28 \%$ above actual production (Table 1). It should be noted that producers involved in the 1980 to 1983 study received cost-sharing funds and technical guidance to assist with implementation of improved water and $\mathrm{N}$ management practices. For these reasons, individual producers were limited to approximately $16 \mathrm{ha}$ and agreed to follow University of Nebraska fertilizer N recommendations. In contrast, producers in 1988 did not receive any special assistance and were asked by the CPNRD to follow University of Nebraska fertilizer N recommendations (voluntary compliance). Lower fertilizer $\mathrm{N}$ recommendations in 1988 , compared to the earlier period, resulted because $N$ rate studies have shown that more credit could be given for residual soil $\mathrm{N}$ and $\mathrm{NO}_{3}-\mathrm{N}$ in irrigation water without reducing yields.

Comparison of current $\mathrm{N}$ management with the earlier study indicates that the ongoing demonstration and educational programs conducted by the Extension Service and the CPNRD have created a producer awareness that has reduced fertilizer inputs over the large study area (164 $\mathrm{kg} \mathrm{N} \mathrm{ha}^{-1}$ in 1988 compared to

Table 1. Summary of corn yields and fertilizer N practices for the Hall County Water Quality Special Project (1980-1983) and the CPNRD Phase II protection area (1988).

\begin{tabular}{|c|c|c|c|c|c|c|c|c|}
\hline \multirow[b]{2}{*}{ Year } & \multirow{2}{*}{$\begin{array}{c}\text { Number } \\
\text { fields }\end{array}$} & \multirow{2}{*}{$\begin{array}{c}\text { Producer } \\
\text { yield }\end{array}$} & \multicolumn{3}{|c|}{ Yield goal } & \multicolumn{2}{|c|}{ Fertilizer $\mathrm{N}$} & \multirow[b]{2}{*}{ Water $\mathrm{NO}_{3}-\mathrm{N}$} \\
\hline & & & Goal & Relative† & Associated N‡ & Recommended & Applied & \\
\hline & & - & - & $\%$ & - & $\mathrm{kg} / \mathrm{ha}$ & 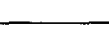 & $\mathbf{m g} / \mathbf{L}$ \\
\hline $\begin{array}{l}1980 \\
1981 \\
1982 \\
1983 \\
1988\end{array}$ & $\begin{array}{r}16 \\
42 \\
47 \\
31 \\
3904\end{array}$ & $\begin{array}{l}7.73 \\
9.74 \\
8.61 \\
7.79 \\
9.99\end{array}$ & $\begin{array}{l}11.12 \\
10.74 \\
10.62 \\
10.62 \\
10.93\end{array}$ & $\begin{array}{r}+44 \\
+10 \\
+23 \\
+36 \\
+9\end{array}$ & $\begin{array}{l}+70 \\
+21 \\
+42 \\
+58 \\
+20\end{array}$ & $\begin{array}{l}160 \\
157 \\
172 \\
178 \\
116\end{array}$ & $\begin{array}{l}160 \\
157 \\
172 \\
178 \\
164 \\
\end{array}$ & $\begin{array}{l}15.7 \\
12.7 \\
18.5 \\
17.5 \\
18 \\
\end{array}$ \\
\hline
\end{tabular}

† Percent greater or less than yield attained.

$\ddagger$ Difference in fertilizer $\mathbf{N}$ recommended for yield goal minus fertilizer $\mathbf{N}$ recommended for yield attained (based on University of Nebraska soil test procedures). 
$-280 \mathrm{~kg} \mathrm{~N} \mathrm{ha}^{-1}$ before 1980) and is reducing the potential for $\mathrm{NO}_{3}-\mathrm{N}$ leaching. Overly optimistic yield goals in 1988 only accounted for $42 \%$ of the average excess $\mathrm{N}$ application rate (i.e., 20 of $48 \mathrm{~kg} \mathrm{ha}^{-1}$ in Table 1) above University of Nebraska recommendations. This average excess $\mathrm{N}$ application rate is not indicative of $\mathrm{N}$ mismanagement by all producers because $22 \%$ of the area received slightly less than the recommended $\mathrm{N}$ rate. Rather, $14 \%$ of the area received $>100$ $\mathrm{kg} \mathrm{N} \mathrm{ha}{ }^{-1}$ in excess of the recommended amount.

A portion of fertilizer $\mathrm{N}$ overapplication, as well as underapplication, can realistically be attributed to problems with application equipment. Accuracy of anhydrous ammonia application equipment and related operator accuracy may not be better than $\pm 22 \mathrm{~kg} \mathrm{ha}^{-1}$ (20 lb acre ${ }^{-1}$ ) unless computerized monitors are utilized. Accepting such an application error, then $32 \%$ of the area was fertilized within the acceptable range and $10 \%$ was below this range, but $58 \%$ of the land received more than $22 \mathrm{~kg} \mathrm{ha}^{-1}$ in excess of the fertilizer $\mathrm{N}$ recommendation.

Producers who apply $\mathrm{N}$ within the recommended range, or less, would contribute less to $\mathrm{NO}_{3}-\mathrm{N}$ contamination of groundwater than those exceeding the recommended range. Fertilizer $\mathbf{N}$ applications that were higher than recommended averaged $76 \mathrm{~kg} \mathrm{~N} \mathrm{ha}^{-1}$ in excess, or $54 \mathrm{~kg} \mathrm{~N} \mathrm{ha}^{-1}$ above the suggested acceptable range. One can only speculate why producers apply considerably more $\mathrm{N}$ than recommended. Possible reasons include (i) compensation for variability in soil nutrient status throughout the field which may not be reflected in soil test data; (ii) anticipated leaching and denitrification losses; (iii) uncertainty over how a given corn hybrid may respond to $\mathrm{N}$ fertilization; (iv) fear of criticism by fellow producers if $\mathrm{N}$ deficiency becomes visible; (v) inadequately based agronomic salesmanship; and (vi) unrealistic yield goals for soils-climate-management. The net effect of all the above can conveniently be grouped into what is frequently termed insurance $\mathrm{N}$. The use of excess $\mathrm{N}$ is perpetuated by availability of relatively inexpensive $N$ fertilizer and the perception that a moderate amount of overfertilization represents a smaller economic risk than a possible yield reduction associated with inadequate N. Environmental considerations should ideally result in more judicious use of fertilizer $\mathrm{N}$.

It is ironic that the group of producers who applied much less fertilizer $\mathrm{N}$ than recommended had the highest yield goals but attained essentially the same yield as those who applied large fertilizer excesses (Fig. 4). Reasons for the overly optimistic yield goals by some producers could be attributed to 1988 being the lst yr for required management practices, even though many producers were familiar with setting realistic yield goals. No explanation is offered for producers who set high yield goals, but failed to apply the recommended amount of fertilizer. It must be recognized that some producers may have set unrealistic yield goals in an attempt to inflate fertilizer $\mathrm{N}$ recommendations.

Unrealistic yield goals only partially account for higher-than-recommended $\mathrm{N}$ application rates. It appears there is a credibility gap between university extension staff (i.e., $\mathrm{N}$ fertilizer recommendations) and

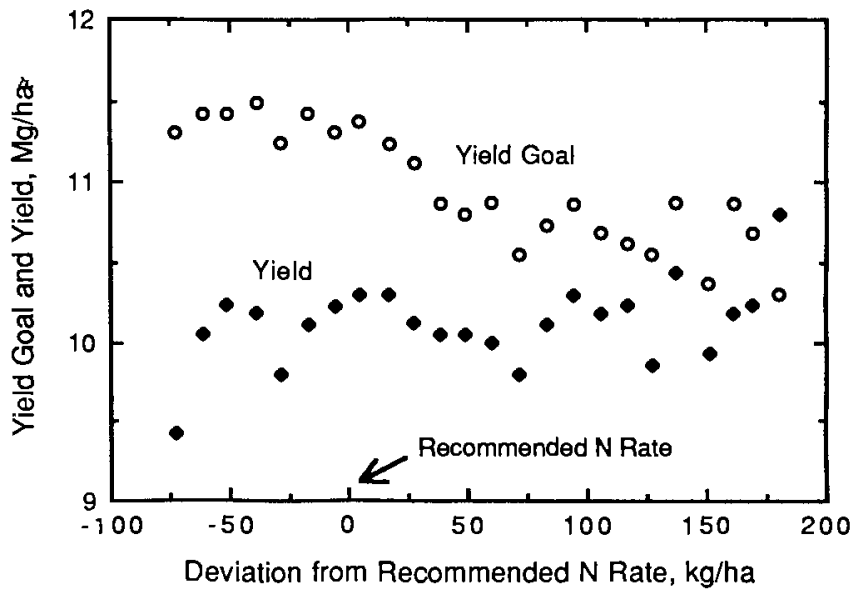

Fig. 4. Corn grain yields and selected yield goals in 1988 for land within the CPNRD Phase II protection area relative to recommended amounts.
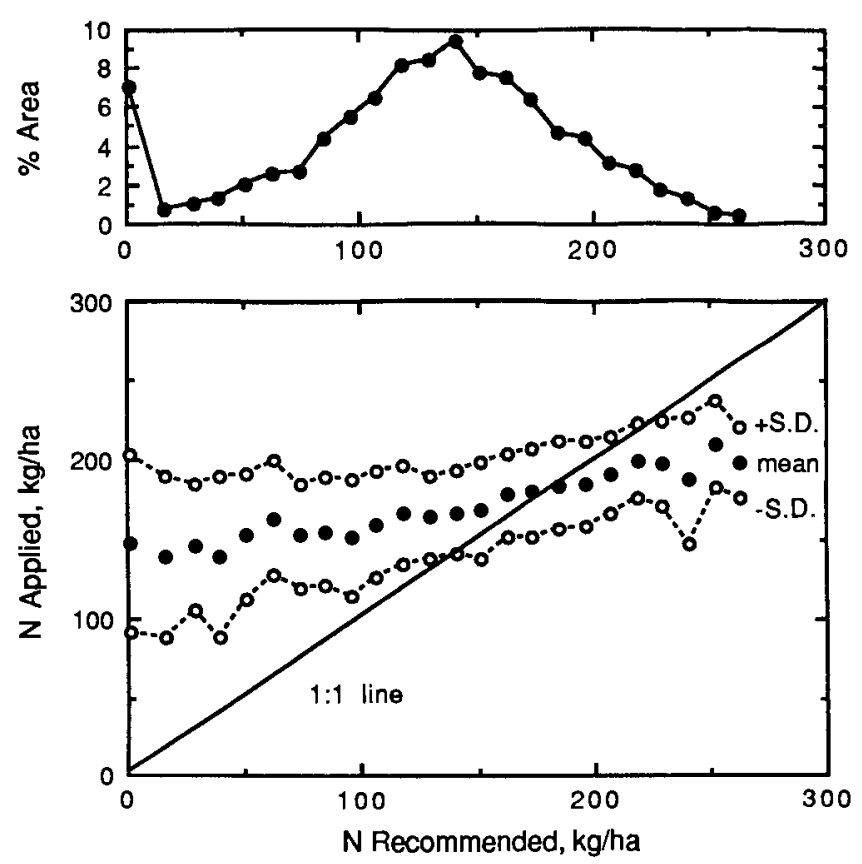

Fig. 5. Distribution and fertilizer $\mathrm{N}$ application rates as related to recommended fertilizer $N$ application rates in 1988 on land within the CPNRD Phase II protection area.

many producers (i.e., actual $\mathrm{N}$ application rates) (Fig. 5). While 34 and $47 \%$ of the area received within 10 and $20 \%$ of the recommended $\mathrm{N}$ application rates, respectively, $50 \%$ of the Phase II protection area had $\mathrm{N}$ application rates more than $20 \%$ above the recommended amounts. To evaluate management considerations that impact fertilizer $\mathrm{N}$ application rates, the compiled data shown in Fig. 5 were subjected to stepwise multiple regression analyses. Dependant variables considered in the prediction of actual $\mathrm{N}$ application rates included (i) fertilizer $\mathrm{N}$ recommended, (ii) yield goal, (iii) residual soil $\mathrm{N}$, and (iv) estimated amount of $\mathrm{NO}_{3}-\mathrm{N}$ in irrigation water during the growing season. Yield goal was the single most important factor considered $\left(R^{2}=0.76\right)$ in the prediction, which was slightly improved by including a term for residual soil $\mathrm{N}$ as follows 


$$
\begin{gathered}
\mathrm{N} \text { Applied }=18.8 \text { (yield goal) }- \\
0.139 \text { (residual } \mathrm{N})-27.3 \quad\left(R^{2}=0.82\right)
\end{gathered}
$$

where $\mathrm{N}$ applied and residual $\mathrm{N}$ had units of kilograms hectare $^{-1}$ and yield goal was expressed as megagrams hectare $^{-1}$. Neither the amount of fertilizer $\mathrm{N}$ recommended nor $\mathrm{NO}_{3}-\mathrm{N}$ expected in irrigation water improved the prediction. This analysis indicates that producers used a value of $18.8 \mathrm{~kg} \mathrm{~N} \mathrm{Mg}^{-1}$ grain (1.05 lb $\mathrm{N} \mathrm{bu}^{-1}$ grain) and considering only approximately $14 \%$ of the $\mathrm{N}$ determined to be available by soil testing procedures. Possible explanations for the low regard for soil test $\mathrm{N}$ values and interpretation include the feeling by some producers that soil variability within a field negates the practical interpretation of the soil test, especially considering the relatively inexpensive nature of $\mathrm{N}$ fertilizer. Another factor is the uncertainty about $\mathrm{NO}_{3}-\mathrm{N}$ leaching between the time of soil sample collection and crop $\mathrm{N}$ uptake.

Peer pressure can't be overlooked in the psychology of soil testing and fertilizer $\mathrm{N}$ recommendations. Producers feel that a yellow tint to corn foliage is indicative of poor $\mathrm{N}$ management and that a yield reduction is likely. Efforts to overcome the green-color mentality can be accelerated if techniques are developed to assure producers that yield reductions are not likely or can be minimized. Groundwater quality concerns will undoubtedly create social pressures that will help motivate producers to become more accountable for all sources of crop $\mathrm{N}$ in the future. The question remains whether voluntary $\mathrm{N}$ and water management practices will provide the intended improvement in groundwater quality or if some form of mandatory regulation will be required. Regardless of any action taken, $\mathrm{NO}_{3}-$
$\mathrm{N}$ movement below the root zone enroute to the aquifer is sufficient to be a serious threat to groundwater quality and makes improvement or cleanup a difficult task within a reasonable period of time. Therefore, the merits of improved $\mathrm{N}$ and water management practices may realistically have to rest largely with a variety of implied affects on groundwater quality. These results indicate that, while progress has been made, a major educational effort is required to change attitudes and motivations that control decisions concerning fertilizer $\mathrm{N}$ application rate.

\section{REFERENCES}

Alberts, E.E., and R.G. Spomer. 1985a. $\mathrm{NO}_{3}-\mathrm{N}$ movement in deep loess soils. ASAE Paper 85-2030. ASAE, St. Joseph, MI.

Alberts, E.E., and R.G. Spomer. 1985b. Dissolved nitrogen and phosphorus in runoff from watersheds in conservation and conventional tillage. J. Soil Water Conserv. 40:153-157.

Bryda, A.P. 1988. NItrate-nitrogen profiles documenting land use practice effects on ground water in and around Sidney, Nebraska. M.S. Thesis, Univ. of Nebraska, Lincoln.

Elliott, L.F., T.M. McCalla, L.N. Mielke, and T.A. Travis. 1972. Ammonium, nitrate, and total nitrogen in the soil water of feedlot and field soil profiles. J. Appl. Microbiol. 28:810-813.

Ellis, J.R., L.N. Mielke, and G.E. Schuman. 1975. Nitrogen status beneath beef cattle feedlots in eastern Nebraska. Soil Sci. Soc. Am. Proc. 39:107-111.

Muir, J., E.C. Seim, and R.A. Olson. 1973. A study of factors influencing the nitrogen and phosphorus contents of Nebraska waters. J. Environ. Qual. 2:466-470.

Saint-Fort, R. 1989. Evaluation of laboratory procedures for prediction of available soil nitrogen in Nebraska. Ph.D dissertation, University of Nebraska-Lincoln.

Schepers, J.S., K.D. Frank, and C. Bourg. 1986. Effect of yield goal and residual soil nitrogen considerations on nitrogen fertilizer recommendations for irrigated maize in Nebraska. J. Fert. Issues 3:133-139.

Spalding, R.F., and L.A. Kitchen. 1988. Nitrate in the intermediate vadose zone beneath irrigated cropland. Groundwater 8:89-95. 